\title{
SZEKULARIZÁCIÓ? DESZEKULARIZÁCIÓ? MERRE TART A VALLÁSI VÁLTOZÁS A VILÁGBAN?
}

\section{SECULARIZATION? DESECULARIZATION? WHERE IS RELIGIOUS CHANGE IN THE WORLD HEADING TO?}

\author{
Rosta Gergely \\ $\mathrm{PhD}$, egyetemi docens \\ Pázmány Péter Katolikus Egyetem Bölcsészettudományi Kar Szociológiai Intézet \\ rosta.gergely@btk.ppke.hu
}

\section{ÖSSZEFOGLALÁS}

A modern világ vallási változását a vallásszociológia sokáig a szekularizáció fogalmával írta le és magyarázta, míg az újabb elméletek többnyire a szekularizációval szemben határozzák meg magukat. Jelen közlemény három célt követ:

(1) a szekularizáció korántsem egységesen értelmezett fogalmának ismertetése;

(2) a vallásszociológiában a szekularizációval szemben megjelent legfontosabb alternatívák rövid bemutatása;

(3) az empirikus vallásszociológiai kutatás egyes kiválasztott eredményeinek ismertetése, és ezek értelmezése a bemutatott elméletek mentén.

Az empirikus elemzés alapjául nemzetközi összehasonlító survey-vizsgálatok eredményei szolgálnak.

\section{ABSTRACT}

Sociology of religion has described and explained the religious change of the modern world for a long time with the notion of secularization, while the newer theories are mostly defining themselves against secularization. The current paper follows three objectives:

(1) a description of the concept of secularization that is by far not uniformly interpreted;

(2) a brief presentation of the most important alternatives to secularization in the sociology of religion;

(3) the presentation of certain selected results of the empirical study of religion and their interpretation along the presented theories.

The empirical analysis is based on the results of international comparative surveys.

Kulcsszavak: vallásszociológia, szekularizáció, modernizáció, vallási individualizáció, vallási piac

Keywords: sociology of religion, secularization, modernization, religious individualization, religious market 
A vallás mint a társadalomtudományos vizsgálódás tárgya kezdetektől fogva jelen volt a szociológia tudományában. Többek között Max Weber, Émile Durkheim és Karl Marx is behatóan foglalkozott a vallás társadalmi szerepével, hatásával és ezek változásával. A társadalmi modernizáció és a vallási változás összefüggésének értelmezése során a kezdetektől használt fogalom a „szekularizáció”, melynek a jelentése körüli viták is közel egyidősek magával a szociológia tudományával. Míg sokáig egyeduralkodónak, megkérdőjelezhetetlennek tünt, hogy a társadalmi modernizáció kizárólag negatív hatással bír a vallás társadalmi jelentőségére, addig az újabb vallásszociológiai elméletek és tézisek többnyire éppen a szekularizációval szemben fogalmazzák meg önmagukat, annak bemutatására és megmagyarázására vállalkozva, hogy szerintük miért nem tarthatók a szekularizációs elmélet előfeltevései és logikai összefüggései. A szekularizáció mára elveszítette korábbi magától értetődőségét, „vallási individualizáció”, „,deszekularizáció”, ,az istenek visszatérése" és más fogalmak mentén nyíltak alternatív utak a vallási változás értelmezéséhez. A vallás, nem utolsósorban a vallási alapú fundamentalizmus és terrorizmus jelentőségének látványos növekedése, de emellett például nagyhatású vallási szereplők (például: II. János Pál pápa, Ferenc pápa, a dalai láma) hatására is újra meg újra a közvélemény érdeklődésének középpontjába kerül, sokak számára élő cáfolatát adva ezzel annak a várakozásnak, hogy a vallás visszafordíthatatlan eltünésre van ítélve a modern világban. De vajon valóban elfelejthetjük mindazt, amit a szociológia korábban gondolt vallás és modernizáció összefüggésérőll?

Jelen írásomban arra teszek röviden kísérletet, hogy (1) bemutassam, mi a ma leginkább elfogadott tartalmi jelentése a szekularizáció korántsem egységesen értelmezett fogalmának; (2) felvázoljam, hogy milyen alternatívák jelentek meg a vallásszociológiában a szekularizációval szemben; és végül (3) az empirikus vallásszociológiai kutatás egyes eredményeinek felvillantásával a teljesség igénye nélkül vázoljam, merre is tart a vallási változás a világban, mennyiben beszélhetünk szekularizációról és/vagy más típusú folyamatokról.

(1) Akadémiai doktori értekezésében Tomka Miklós szisztematikus alapossággal gyüjtötte össze a szekularizációs elmélet, illetve ahogy ö nevezte, a szekularizációs tézis lehetséges értelmezéseit, és az ezekkel szemben megfogalmazható számos kritikát (Tomka, 2011). Ezek részletes ismertetésére itt nincs lehetőség, de a legföbb vitapont rövid bemutatásán keresztül képet kaphatunk a fogalom sokrétü jelentéséről, és arról is, mit érthetünk ma szekularizáció alatt.

A szekularizációval kapcsolatban a fö kérdés általában az, hogy a modern kor vallási változását egy szükségszerü, visszafordíthatatlan és végső soron a vallás eltünéséhez vezetö folyamatként írhatjuk-e le. Ezen állítások mindegyik eleme, tehát a szükségszerűség, a visszafordíthatatlanság és a vallás eltủnése is heves viták tárgya volt, és tárgya a mai napig a vallásszociológiában. Ez néha még kiegészül azzal is, hogy vajon a szekularizációt ezen elmélet képviselői mennyiben tartják kivánatos célnak. 
Számos empirikus elemzés igyekezett cáfolni a modernizáció és a vallás viszszaszorulása közti összefüggés szükségességét, egyebek között olyan magas fokú modernizációval jellemezhető társadalmakat hozva fel ellenpéldaként, mint az USA vagy Dél-Korea, amelyekben jól megférni látszik egymás mellett a modernizáció és a vallásosság magas vagy egyenesen növekvő foka. Hasonló a helyzet a visszafordíthatatlansággal is, mellyel szemben többen inkább hullámzó vonalként látják a vallás jelentőségének változását történeti távlatokban mérve, mintsem egyenes irányú csökkenésként. A vallás teljes eltünésére vonatkozó prognózis annak kérdését is felveti, meddig terjednek a tudományos kijelentések határai, hiszen jelenleg egyetlen olyan társadalom sincs, melyet teljes mértékben elvallástalanodottnak tekinthetnénk, s hogy a jelenlegi trendek a jövőben hogyan folytatódnak, azt ceteris paribus is nehéz előre jelezni. A szekularizáció kívánatosságára vonatkozó feltételezések pedig arra mutatnak rá, hogy a fogalom korántsem mentes bizonyos ideológiai mellékzöngéktöl, és erős annak kísértése, hogy a szekularizációt a szekularizmussal azonosítsák. Mindenesetre a szekularizáció mint tudományos fogalom nyilvánvalóan csak bizonyos tényállások és az ezek mögött meghúzódó társadalmi törvényszerüségek magyarázatára vállalkozhat, s nem tehető felelőssé azért, legfeljebb konstatálni lehet, ha politikai-ideológiai célkitüzések tárgyává válik.

A szekularizációs tézis képviselőinek legfőbb ellenérve a fenti kritikával szemben általában úgy hangzik, hogy ezek az állítások nem felelnek meg annak, amit ők a szekularizációról ténylegesen mondanak. Már a szociológia alapító atyái, Durkheim és Weber sem gondolták úgy, hogy a racionalizáció és a társadalmi differenciálódás hatására a vallás teljes mértékben el fog tủnni, és egy tudományos világkép fogja átvenni a helyét. A szekularizáció későbbi képviselői pedig többnyire határozottan tiltakoznak az ellen a feltételezés ellen, hogy a fenti állitásokat képviselnék, és többnyire rámutatnak arra, hogy kritikusaik a szekularizáció könnyebb cáfolata érdekében tulajdonítják nekik ezeket a téziseket (Wilson, 1998; Bruce, 2006; Pollack, 2009).

De akkor mit is értenek a szekularizáció fogalma alatt azok a vallásszociológusok, akik ma is ezt az elméletet képviselik? Bár e tekintetben nincs egységes álláspont, az egyes megközelítések közös részeként az kristályosodik ki, hogy a szekularizáció a vallás csökkenő jelentőségének folyamatát jelenti a modernizálódó társadalmakban. Egy valamivel részletesebb meghatározás így hangzik: „A modernizáció folyamatai - a szekularizáció központi tézise szerint - végső soron negatív hatással vannak a vallási közösségek, vallási gyakorlatok és meggyöződések stabilitására és vitalitására, és csökkentik ezek elfogadottságát"1 (Pollack,

\footnotetext{
${ }^{1}$ „Prozesse der Modernisierung haben - so die Kernthese der Säkularisierungsthese - einen letztlich negativen Einfluss auf die Stabilität und Vitalität von Religionsgemeinschaften, religiösen Praktiken und Überzeugungen und vermindern deren Akzeptanz" - a szerző fordítása.
} 
2009, 20.). Ez a hatás Detlef Pollack szerint sem szükségszerü, sem visszafordíthatatlan, sem pedig kívánatos, hanem valószínüségi. Ahogyan a legtöbb társadalmi törvényszerüségről azt tartjuk, hogy nem determinisztikus, hanem sztochasztikus módon fejti ki hatását, úgy ez a szekularizációra is vonatkozik. Amennyiben kivételek mutatkoznak egy adott szabály alól, azok ugyan gyengítik azt, de ameddig nem a kivételek válnak általánossá, addig ezek tekinthetők speciális eseteknek.

A társadalmi modernizáció egyes, a szekularizációt elősegítő folyamatai alatt mindenekelőtt a funkcionális differenciálódást és a racionalizálódást szokás érteni. A funkcionális differenciálódás hatására a társadalomban az egyes funkciók betöltésére önálló alrendszerek jönnek létre, melyek saját logikájuk szerint müködnek, s ezáltal a vallás korábbi átfogó értelmezési funkciója egyre inkább visszaszorul a társadalmi élet egyes területeiröl. A racionalizálódás pedig a világ tudományos megismerésének igényét, az ok-okozati kapcsolatok keresését, és ennek a szemléletnek a terjedését állítja szembe a vallási alapú világképpel. De ezek mellett a modernizáció más folyamatait, így az iparosodást, a városiasodást vagy a demokratizálódást is a vallás számára negatív következményekkel járó jelenségek közé sorolják a szekularizáció képviselői.

A szekularizációval szembeni további kritikai pontok szisztematikus bemutatására itt nem kerülhet sor, de az alternatív elméletek ismertetése során némelyikük még említésre fog kerülni.

(2) A vallási változás másik fő elmélete a szekularizáció mellett a vallási individualizáció, amely abból indul ki, hogy modernizáció és vallás nem állnak egymással összeegyeztethetetlen kapcsolatban. Ez nem azt jelenti, hogy a modernizáció hatás nélkül volna a vallásra, sokkal inkább azt, hogy ez a hatás nem feltétlenül negatív. Fontos alappillére az individualizációs elméleteknek, hogy különbséget tesznek az egyházhoz kötődö vallásosság és a hit, vagy általánosabb értelemben a nem egyházias vallásosság között. Ez a különbségtétel sokszor egyben kritikaként fogalmazódik meg a szekularizációval szemben, nevezetesen, hogy utóbbi elmélet egyenlőséget tesz vallás és egyház, illetve vallásosság és egyháziasság között, és ezáltal figyelmen kívül hagy olyan jelenségeket, amelyek szintén a vallási változás részei.

Nagyon leegyszerüsítve a vallási individualizáció fő tézise az, hogy az egyháziasság csökkenése nem jár együtt a vallás egészének eltűnésével, sokkal inkább egy alakváltásnak vagyunk tanúi. A vallás - csakúgy, mint az egyéni élet sok más területe is - egyéni választások tárgyává válik az elmélet képviselői szerint, és a választás nem pusztán a vallás vállalása és elutasítása közti kétkimenetü döntést jelent, ennél sokkal szélesebb a paletta. Az egyéni vallásosság eszerint egyre kevésbé nyilvánul meg olyan módon, hogy az individuum egy egyház, felekezet tanításával teljes egészében azonosul, sokkal elterjedtebbé válik a válogatás a saját és más vallási tradíciók tanai közül, melynek eredményeképpen az egyénileg barkácsolt vallások színes egymásmellettisége jön létre. Fontos közös 
jellemzője a vallási individualizáció különböző képviselőinek, hogy az egyházias vallásosság csökkenését, valamint az individuális vallásosság erősödését komplementer folyamatokként látják, azaz szerintük a spiritualitás, az alternatív vallási praktikák, a távol-keleti vallási hagyományok terjedése az egyházias vallásosság visszaszorulásából táplálkozik (Luckmann, 1967; Hervieu-Léger, 2000; Davie, 2002).

Egy másik, a vallási változásra és az egyes társadalmak vallásosságának eltérő szintjére adott elméleti magyarázat a racionális döntéselméleti alapokon álló vallási piac elmélete. Ez a tézis, melyet szokás kínálati alapú (supply-side) megközelítésnek is nevezni, abból indul ki, hogy a vallásosság társadalmi szintje alapvetően attól függ, hogy mennyire nyílt és plurális a vallási kínálat, azaz az egyházak, vallási közösségek piaca. Ez az eredendően közgazdaságtani szemléleten alapuló elmélet azt állítja, hogy minél több szereplős a piac, és minél szabadabb a verseny közöttük - azaz minél kevésbé szól bele az állam a vallási ügyekbe, akár korlátozóan, akár támogatóan -, annál valószínúbb, hogy valódi verseny jön létre. Ennek pedig az lesz az eredménye, hogy a „vallási szolgáltatók”, azaz a kis és nagy egyházak igyekeznek minél inkább megfelelni a potenciális hívek vallási igényeinek, ami végső soron azt eredményezi, hogy nagy valószínűséggel mindenki megtalálja a saját elképzeléseinek leginkább megfelelö egyházat.

Ez az eredeti elmélet, nem titkoltan, arra próbált magyarázatot adni, hogy miként lehet az Egyesült Államokban, a világ egyik legfejlettebb országában jóval magasabb a vallásosak aránya, mint Nyugat-Európa sok országában. A vallási piac elméletének képviselői szerint történelmi okokból a legtöbb országban vallási monopólium vagy legfeljebb duopólium jött létre, ami a vallási igények alacsony szintü kielégítését eredményezte, és végső soron a „kliensek” elfordulását az egyházaktól (Iannaccone, 1991; Stark-Iannaccone, 1994; Stark-Finke, 2000).

Kelet- és Közép-Európa vallási változásainak értelmezése során is rendszeresen előkerül ez az elmélet, hiszen a rendszerváltással véget ért az egyházüldözés, és szabaddá vált a vallásgyakorlat, azaz elvileg olyan helyzet jött létre, amely kedvezett a szabad vallási piacnak, s ebből következően a vallás erősödése volt várható az elmélet alapján.

Fontos előnye a vallási piac elméletének, hogy a vallásokat, egyházakat nem a modernizáció passzív elszenvedőiként látja. A szekularizáció esetében ez is gyakran említett kritika, nevezetesen hogy a társadalmi modernizációt olyan folyamatként írja le, melyben a vallások tehetetlenül sodródnak, nincs lehetőségük sorsuk saját irányítására. Más kérdés, hogy a közgazdasági megközelítés hívei a vallási keresletet is másképp tekintik, társadalmanként többé-kevésbé azonosnak és állandónak tételezve azt, ami azonban csak akkor válik vallásossággá, ha találkozik a megfelelő kínálattal.

Az elméleti igényủ magyarázatokon túl több olyan mű is született a közelmúltban, amely a vallás eltűnése helyett annak visszatérésével foglalkozik. A szeku- 
larizációs elmélet egyik korábbi fö képviselöje, Peter L. Berger Desecularization címmel adott ki könyvet (1999); a Vallások visszatérése (Riesebrodt, 2000) és az Istenek visszatérése (Graf, 2004) két fontos német vallástudományi mü a 2000-es évek elejéről. Ezek részben annak felismeréséből fakadnak, hogy a vallás korábban prognosztizált eltünése nem következett be, és részben a 2001. szeptember 11. utáni új helyzetre, valamint annak huntingtoni értelmezésében a vallások szerepére reflektálnak (Huntington, 1996). Speciálisan a kelet-európai régió vallási változásának a szekularizációhoz képest lehetséges alternatív magyarázatait pedig Máté-Tóth András tekintette át (2014).

Az eddigiekben igen röviden összefoglalt elméletek mindegyike tulajdonképpen ugyanarra a kérdésre keresi a választ: hogyan és miért változik a vallás társadalmi helye és jelentősége a modern világban. A különböző megközelítések között feszülő ellentmondások egy része az eltérő kiinduló feltevésekre, a vallás eltérő értelmezésére vezethető vissza. Nagyobb részük azonban empirikus ellenőrzést igényel, ahol azt kell megvizsgálni, hogy a hozzáférhető empirikus vallásszociológiai adatok melyik elmélet érvényességét támasztják inkább alá. A cikk harmadik részében erre teszek kísérletet, előrebocsátva, hogy a rendelkezésre álló, többnyire népszámlálásokból, kérdőíves megkérdezésekből és hivatalos statisztikákból származó adatok révén leginkább az individuális szintủ vallási változásról, azaz a vallásosság különböző mutatóival mért változásról lehet kijelentéseket tenni. Tehát például az egyházak politikai vagy gazdasági befolyásának változását nem tudjuk ilyen módon mérni.

További korlátja a bemutatásra kerülő eredményeknek, hogy a nemzetközi összehasonlítást lehetővé tevő vizsgálatok viszonylag rövid múltra tekintenek vissza, így a nyugat-európai szekularizációs folyamatok egyik legfontosabb évtizedének tekintett 60-as évekre vonatkozóan még nincsenek ilyen átfogó adatok. A Nyugat-Európán kívüli országok esetében pedig gyakran még rövidebb az idősor. Ily módon az adatok hozzáférhetősége épp azt a kritikát teszi nehezen cáfolhatóvá, hogy a szekularizáció csak a kereszténységre, és azon belül is csak a nyugat-európai országokra vonatkozóan tekinthető érvényesnek.

Egy harmadik korlát pedig az adatok természetéből fakad: az összehasonlító vizsgálatok nemzetközi kérdőíves vizsgálatok, ennek megfelelően az ezekben feltett kérdésekre adott válaszok vizsgálhatók csupán. Ez pedig teret ad egy gyakran említett ellenvetésnek a szekularizációval szemben, mivel főleg a korai vizsgálatokban a vallásosságot többnyire annak egyházhoz kötődő formáin keresztül mérték, az individuális vallásosságot alig.

(3) A vallási változás empirikus elemzése során csak néhány alapvető eredmény felvillantására nyílik lehetőség itt. Ezek közé tartoznak a vallási hovatartozásnak, a vallásgyakorlatnak és a vallási meggyőződésnek olyan indikátorai alapján tapasztalt változások, mint a felekezethez tartozás, a templomba járás gyakorisága vagy az istenhit. Az 1. táblázat adatai azt mutatják, hogy mind a ki- 
választott nyugat-európai országokban, mind az Egyesült Államokban a vallásosság mutatóinak mennyiségi csökkenése a jellemző változás. Találni kivételeket is ez alól, ahol inkább stagnálást tapasztalni, például Olaszországban a vallásgyakorlat és a hit terén, vagy egyes skandináv országokban a templomba járás gyakorisága esetében. De ezek egyrészt nem az általános trendet jelzik, másfelől több esetben már a vizsgált periódus kezdetén olyan alacsony volt a vizsgált mutatók értéke, hogy további szignifikáns csökkenés már nem volna lehetséges. Fontos ugyanakkor arra is rámutatni, hogy a változás nagyon eltérő szintekről, és nagyon különböző mértékben valósult meg. Így például az USA-ban mindhárom érték a legmagasabbak között van, és a csökkenés sem olyan drasztikus, mint például Nagy-Britanniában vagy Belgiumban.

1. táblázat. A vallásosság változása Nyugat-Európában és az Egyesült Államokban, 1981-2008 (\%)

\begin{tabular}{|c|c|c|c|c|c|c|c|c|c|}
\hline \multirow{2}{*}{ Ország } & \multicolumn{3}{|c|}{ Felekezethez tartozás } & \multicolumn{3}{|c|}{$\begin{array}{c}\text { Min. heti } \\
\text { templomba járás }\end{array}$} & \multicolumn{3}{|c|}{ Istenhit } \\
\hline & 1981 & 2008 & vált. & 1981 & 2008 & vált. & 1981 & 2008 & vált. \\
\hline Belgium & 84 & 57 & -27 & 30 & 11 & -19 & 87 & 61 & -26 \\
\hline Dánia & 94 & 88 & -6 & 3 & 3 & 0 & 68 & 63 & -5 \\
\hline Franciaország & 74 & 49 & -25 & 12 & 6 & -6 & 68 & 52 & -16 \\
\hline Ny-Németország & 91 & 84 & -7 & 22 & 10 & -12 & 82 & 73 & -9 \\
\hline Nagy-Britannia & 91 & 55 & -36 & 14 & 12 & -2 & 83 & 65 & -18 \\
\hline Izland & 99 & 92 & -7 & 2 & 4 & +2 & 81 & 72 & -9 \\
\hline Írország & 99 & 87 & -12 & 82 & 40 & -42 & 97 & 90 & -7 \\
\hline Olaszország & 94 & 82 & -12 & 36 & 34 & -2 & 90 & 91 & +1 \\
\hline Málta & 100 & 97 & -3 & 92 & 77 & -15 & 100 & 99 & -1 \\
\hline Hollandia & 63 & 49 & -14 & 27 & 15 & -12 & 72 & 58 & -14 \\
\hline Észak-Írország & 97 & 78 & -19 & 53 & 41 & -12 & 97 & 91 & -6 \\
\hline Norvégia & 96 & 80 & -16 & 6 & 6 & 0 & 76 & 56 & -20 \\
\hline Spanyolország & 91 & 75 & -16 & 41 & 17 & -24 & 92 & 76 & -16 \\
\hline Svédország & 93 & 66 & -27 & 6 & 5 & -1 & 60 & 46 & -14 \\
\hline USA & $93^{\mathrm{a}}$ & 83 & -10 & 47 & $36^{\mathrm{b}}$ & -11 & 96 & $88^{\mathrm{c}}$ & -8 \\
\hline
\end{tabular}

European Values Study 1981, 2008; World Values Survey 1981, 2005-2009, 2010-2014; General Social Survey 1982, 2008 adatai alapján saját szerkesztés a1982-es adat, ${ }^{\mathrm{b}} 2006$-os adat, ${ }^{\mathrm{c}} 2011$-es adat 
A volt szocialista országokkal foglalkozó táblázat más képet mutat (2. táblázat). Itt is találunk viszonylag jelentős, két számjegyü csökkenést például a volt Kelet-Németország esetében a felekezethez tartozás és az istenhit terén, vagy Lengyelországban a heti templomba járás gyakoriságában. Ennél jóval jelentősebb az az emelkedés, amit a vallási kötődés és meggyőződés dimenzióiban mindenekelőtt az ortodox többségü országokban (Oroszország, Bulgária), de a jelentős ortodox kisebbséggel bíró balti államokban is tapasztalni. Itt is felvethetö, csak ellentétes előjellel, mint a skandináv országokkal kapcsolatban: Románia és Lengyelország már az időszak elején is 90\%-ot meghaladó arányban mutatkozott vallásosnak ezen indikátorok alapján, további emelkedés alig képzelhető el (de Romániában megtörtént).

2. táblázat. A vallásosság változása egyes kelet- és közép-európai országokban, 1990-2008 (\%)

\begin{tabular}{|l|c|c|c|c|c|c|c|c|c|}
\hline \multirow{2}{*}{\multicolumn{1}{|c|}{ Ország }} & \multicolumn{3}{|c|}{ Felekezethez tartozás } & \multicolumn{3}{c|}{$\begin{array}{c}\text { Min. heti } \\
\text { templomba járás }\end{array}$} & \multicolumn{3}{c|}{ Istenhit } \\
\cline { 2 - 11 } & $\mathbf{1 9 9 0}$ & $\mathbf{2 0 0 8}$ & vált. & $\mathbf{1 9 9 0}$ & $\mathbf{2 0 0 8}$ & vált. & $\mathbf{1 9 9 0}$ & $\mathbf{2 0 0 8}$ & vált. \\
\hline Lengyelország & 96 & 95 & -1 & 66 & 53 & -13 & 97 & 96 & -1 \\
Szlovénia & 74 & 71 & -3 & 23 & 17 & -6 & 63 & 66 & +3 \\
Csehország & 40 & 29 & -11 & 8 & 8 & 0 & 35 & 36 & +1 \\
K-Németország & 38 & 23 & -15 & 9 & 4 & -5 & 36 & 21 & -15 \\
Észtország & 13 & 31 & +18 & 3 & 4 & +1 & n.a. & 48 & - \\
Magyarország & 58 & 55 & -3 & 14 & 9 & -5 & 65 & 71 & +6 \\
Lettország & 37 & 65 & +28 & 3 & 6 & +3 & 58 & 77 & +19 \\
Oroszország & 34 & 62 & +28 & 2 & 5 & +3 & 44 & 77 & +33 \\
Románia & 94 & 98 & +4 & 19 & 28 & +9 & 94 & 98 & +4 \\
Bulgária & 34 & 74 & +40 & 6 & 6 & 0 & 40 & 75 & +35 \\
\hline
\end{tabular}

European Values Study 1990, 2008; World Values Survey 1990 adatai alapján saját szerkesztés

A kelet- és közép-európai országok 1990 utáni vallási változása tehát semmi esetre sem írható le hasonlóan egységes trenddel, mint Nyugat-Európa esetében. A szekularizációs tendenciák keverednek a vallási újraéledés folyamataival a régióban.

Az egyháztól többé-kevésbé független, individuális vallásosságra vonatkozóan nem találni olyan mutatót, amely egy hosszabb időtávra vonatkozóan nyújtja az országok közötti összehasonlítás lehetőségét. Ez esetben jobb híján a korcsoportok közötti összehasonlításhoz folyamodhatunk, arra hivatkozva, hogy a vonatkozó 
vizsgálatok szerint a vallási változás jelentős mértékben a generációk közötti változásként írható le, ahol az életúton belüli változás, ha nem is elhanyagolható, de jóval kisebb.

Amennyiben a vallási individualizáció folyamatai az egymást követő generációkat egyre jobban jellemzik, úgy azt várhatjuk, hogy a fiatalabb generációk körében elterjedtebbek az ehhez kapcsolható nézetek, tanok, gyakorlatok. A 3. táblázat egy kiválasztott mutató, az Istenben mint nem - a tradicionális egyházak tanításának megfelelö - konkrét személyben, hanem mint valamiféle szellemi lényben vagy életerőben való hit alapján mutatja be ezeket a generációs különbségeket Nyugat- és Kelet-Európában. Az eltérések itt sem rendezhetők egyetlen általános trend alá, s leginkább az jellemző, hogy a generációs különbségek nem nagyok. Ahol a fiatalok nagyobb arányban hisznek egy ilyen diffúz istenképben, mint az idősebbek, többnyire ott sem, vagy csak alig haladja meg a 10 százalékpontot az eltérés, és Szlovénia kivételével nincs még egy olyan ország, ahol a fiatalok többsége hinne valamilyen szellemi lény vagy életerö létében. Fontos azt is észrevenni, hogy a generációk közötti emelkedés nemcsak olyan esetekben történt, ahol ez az amúgy csökkenő hagyományos vallásosság helyére léphet (például Írország), hanem nem ritka az olyan eset, ahol a vallás hagyományosabb mutatóival párhuzamos az individuális vallásosság erősödése is (például Románia) vagy mindkettő párhuzamos csökkenése (például: Hollandia, Norvégia, Svédország).

Hogyan értelmezhetjük ezeket az eredményeket röviden, a bemutatott elméletek tükrében? A vallásosság egyházhoz köthető formáinak fokozatos visszaszorulása a nyugati keresztény világban a vizsgált időszak során meglehetősen általános jelenségnek tủnik. Ezzel párosulnak vallási individualizációs jelenségek is, de ezek egyfelől nem lépnek egyértelmüen a helyébe a vallásosság új típusaként jelentőségében csökkenő hagyományos formáknak, hanem gyakran azzal párhuzamosan változnak. Másfelől pedig, ahol emelkedést tapasztalni, ott ennek mértéke gyakran elmarad a hagyományos vallási mutatók által mért csökkenéstől. A vallási piac modellje nagyon nehezen értelmezhető a nyugat-európai kontextusban, hiszen a vallási piac ezekben az országokban többnyire szabad, még ha több esetben (például skandináv protestáns államvallások) van egy történelmileg kitüntetett vallás.

A volt keleti blokkban szekularizációs és deszekularizációs folyamatok is tapasztalhatók. Szembetűnő, hogy a vallásosság emelkedésének mértéke a vallásgyakorlat mutatóinak esetében a legkisebb. Sokkal erőteljesebb a meggyőződés (istenhit), valamint a vallási identitást leginkább kifejező vallási hovatartozás esetében. Az is megfontolandó, hogy noha első látásra a vallási piac elmélete megmagyarázhatja a szabaddá vált piacon a vallás erősödését, közelebbről szemlélve mégsem arról van szó, hogy az egymással versenyző vallási közösségek miatt virágzik ki a vallásos táj, hiszen a legjelentősebb emelkedés az 
erősen vallási monopóliumon alapuló, és ezt megőrizni is szándékozó ortodox országokban mutatkozik. Itt feltehetőleg sokkal inkább a vallási és a nemzeti identitás közös erősödéséről van szó 1990 után. (Erről bővebben lásd PollackRosta, 2017.)

3. táblázat. A valamilyen szellemi lényben vagy életerőben, de nem egy személyes Istenben hívők aránya korcsoportonként (\%)

\begin{tabular}{|c|c|c|c|c|}
\hline Ország & 18-29 & $30-49$ & 50 & $\begin{array}{c}\text { különbség } \\
\text { (legfiatalabb-legidősebb) }\end{array}$ \\
\hline Belgium & 37 & 40 & 36 & +1 \\
\hline Bulgária & 38 & 47 & 50 & -12 \\
\hline Csehország & 26 & 31 & 31 & -5 \\
\hline Dánia & 30 & 37 & 35 & -5 \\
\hline Franciaország & 34 & 35 & 33 & +1 \\
\hline Magyarország & 29 & 24 & 18 & +11 \\
\hline Írország & 30 & 28 & 20 & +10 \\
\hline Olaszország & 26 & 30 & 19 & +7 \\
\hline Litvánia & 34 & 35 & 27 & +7 \\
\hline Málta & 32 & 31 & 20 & +12 \\
\hline Hollandia & 35 & 47 & 44 & -9 \\
\hline Norvégia & 33 & 39 & 45 & -12 \\
\hline Lengyelország & 15 & 10 & 8 & +7 \\
\hline Románia & 52 & 48 & 42 & +10 \\
\hline Oroszország & 18 & 23 & 19 & -1 \\
\hline Szlovákia & 40 & 29 & 29 & +11 \\
\hline Szlovénia & 57 & 54 & 44 & +13 \\
\hline Spanyolország & 28 & 30 & 21 & +7 \\
\hline Svédország & 40 & 43 & 49 & -9 \\
\hline Nagy-Britannia & 35 & 39 & 42 & -7 \\
\hline Ny-Németország & 43 & 48 & 46 & -3 \\
\hline K-Németország & 12 & 15 & 21 & -9 \\
\hline
\end{tabular}

European Values Study 2008 alapján saját szerkesztés 
Az Európán kívüli világ vallási folyamatai a fentinél jóval összetettebb képet mutatnak, melynek teljes körü bemutatása jelentősen meghaladná egy rövid tanulmány kereteit. Nem térhettünk ki egyes országok specifikumaira, sem arra, hogy a szekularizációs jelenségek nemcsak keresztény kontextusban figyelhetők meg (lásd például Japánt), vagy arra, hogy a keresztény hagyományok talaján erőteljes fellendüléssel is találkozhatunk (például a pünkösdi mozgalmak felfutása Dél-Amerikában). Annak bemutatására volt itt lehetőség, hogy Európában és az Egyesült Államokban egyidejüleg szekularizációs és vallási individualizációs folyamatok is megfigyelhetők, ami legalábbis megkérdőjelezi a szekularizáció elméletének egyre szélesebb körü elutasítását a vallásszociológián belül.

A cikk a Nemzeti Kutatási, Fejlesztési és Innovációs Hivatal NKFI Alapjából támogatott K 119679 nyilvántartási számú, „Vallási változás Magyarországon” címü kutatási projekt támogatásával valósult meg.

\section{IRODALOM}

Berger, P. L. (ed.) (1999): The Desecularization of the World: Resurgent Religion and World Politics. Washington, DC: Ethics and Public Policy Center

Bruce, S. (2006): What the Secularization Paradigm Really Says. In: Franzmann, M. - Gärtner, Ch. - Köck, N. (Hrsg.): Religiosität in der säkularisierten Welt. Wiesbaden: Verlag für Sozialwissenschaften, 39-48.

Davie, G. (2002): Europe: The Exceptional Case: Parameters of Faith in the Modern World. London: Darton, Longman and Todd

Graf, F. W. (2004): Die Wiederkehr der Götter: Religion in der modernen Kultur. München: Beck Hervieu-Léger, D. (2000): Religion as a Chain of Memory. Cambridge: Polity Press

Huntington, S. Ph. (1996): The Clash of Civilizations and the Remaking of World Order. New York: Simon \& Schuster

Iannaccone, L. (1991): The Consequences of Religious Market Structure: Adam Smith and the Economics of Religion. Rationality and Society, 3, 156-177. https://ir.lib.uwo.ca/cgi/viewcontent.cgi?referer=https://www.google.com/\&httpsredir=1\&article=1012\&context=economicsperg_ppe

Luckmann, T. (1967): The Invisible Religion: The Problem of Religion in Modern Society. New York: Macmillan

Máté-Tóth A. (2014): Vallásnézet. A kelet-közép-európai átmenet vallástudományi értelmezése. Kolozsvár: Korunk-Komp-Press

Pollack, D. (2009): Rückkehr des Religiösen? Tübingen: Mohr Siebeck

Pollack, D. - Rosta G. (2017): Religion and Modernity. An International Comparison. Oxford: Oxford University Press

Riesebrodt, M. (2000): Die Rückkehr der Religionen: Fundamentalismus und der „Kampf der Kulturen". München: Beck

Stark, R. - Finke, R. (2000): Acts of Faith: Explaining the Human Side of Religion. Berkeley, Los Angeles: University of California Press 
Stark, R. - Iannaccone, L. R. (1994): A Supply-Side Reinterpretation of the "Secularization" of Europe. Journal for the Scientific Study of Religion, 33, 230-252. https://www.unil.ch/files/ live/sites/issr/files/shared/Iannaccone_Stark.pdf

Tomka M. (2011): A vallás a modern világban. Budapest: Semmelweis Egyetem Mentálhigiéné Intézet-Párbeszéd (Dialógus) Alapítvány

Wilson, B. (1998): The Secularisation Thesis: Criticisms and Rebuttals. In: Laermans, R. - Wilson, B. - Billiet, J. (eds.): Secularisation and Social Integration: Papers in Honour of Karel Dobbelaere. Leuven: Leuven University Press, 45-65. 